\title{
Teoria dos campos e políticas ambientais locais
}

\section{Field Theory and Local Environmental Policies}

\author{
Amalia Maria Goldberg GODOY*
}

\begin{abstract}
RESUMO
Muitos estudos apontam os aspectos positivos dos conselhos gestores e são consensuais que, uma vez consolidados, eles tendem a ampliar o raio de ação das políticas ambientais locais. Este artigo reavalia esta visão e, para isso, utiliza a teoria dos campos alicerçada em Bourdieu (1999) e Fligstein (2001) e tem como objetivos mapear e discutir os interesses dos grupos, em disputa contínua, dentro do Conselho de Defesa de Meio Ambiente de Maringá-COMDEMA e seus desdobramentos sobre a discussão e o direcionamento das políticas ambientais. Para isso, foram realizados revisão bibliográfica sobre o tema, levantamento de atas do conselho - período 1993 a 2006 - e entrevistas com atores-chave. Entre os principais resultados, ressalta-se que a teoria dos campos permitiu verificar que as estratégias traçadas pelos grupos, que visam ao alcance de interesses específicos, em alguns momentos permitiram que os mesmos se associassem e, em outros, se confrontassem. De maneira geral, o jogo travado entre as diferentes posições, no campo ambiental, filtrou questões relevantes e fez com que prevalecesse somente a visão de que se deve cumprir a lei. Com isso, perdeu-se um espaço importante para avançar na discussão de planejamento do desenvolvimento com sustentabilidade ambiental.
\end{abstract}

Palavras-chave: conselho de meio ambiente; conflitos; Bourdieu e Fligstein.

\begin{abstract}
Many research studies point out the positive aspects of the management councils and defend that, once consolidated, they tend to enlarge the range of action of local environmental policies. This article re-evaluates this vision and for that it uses the approach of the theory of the field by Bourdieu (1999) and Fligstein (2001), and aims to discuss the interest of groups in continuing dispute within the Council of Environment Maringá (COMDEMA) and its results on the agenda for discussion and action by environment policies. For this, the literature on the subject was reviewed, the council minutes from 1993 to 2006 were analyzed, and interviews with key actors were done. The main results are that the theory of fields showed strategies drawn from groups that aim to reach specific interests. In some moments they would associate with each other, and in others they would create confrontation. Overall, this game between different groups within the environmental field filtered what is considered "principal" environment and made the view that should comply with the law prevail, leaving aside the discussion of advance planning development with environmental sustainability.
\end{abstract}

Key-words: Environment council, Maringá, conflicts, Bourdieu and Fligstein.

\footnotetext{
" Doutora em Meio Ambiente e Desenvolvimento (UFPR). Professora Associada do Departamento de Economia e do Programa de Pós-Graduação em Economia da Universidade Estadual de Maringá. Email: amggodoy@uem.br
} 


\section{Introdução}

A Constituição da República Federativa do Brasil de 1988, além de enfatizar a descentralização, legitima as formas coletivas de formulação e decisão das políticas públicas, particularmente, através dos conselhos gestores ${ }^{1}$. A implantação dos conselhos gestores começou na área da saúde e se estendeu para as áreas da criança e do adolescente, assistência social, educação, trabalho, desenvolvimento rural e para o meio ambiente, com os artigos $12, \S 1^{\circ}$ e 20 da Resolução Conama n. 237, de 19 de dezembro de 1997 (CONAMA, 1997).

A maior parte das discussões sobre participação enfatiza aspectos positivos, tanto do processo democrático quanto dos resultados e um avanço na construção da sustentabilidade local (OSTROM, 2004; RIBOT, 2004), além de salientar condicionantes considerados fundamentais para a boa qualidade dos conselhos que ajudam na construção da sustentabilidade do desenvolvimento (MMA/BID, 2002). No entanto, outros estudos constatam vários obstáculos e poucos avanços na implantação dos conselhos ambientais (TONI; KAIMOWITZ, 2003; TONI, 2004) e indicam que a condução e a decisão coletivas têm resultados específicos em cada região, o que evidencia a influência do ambiente institucional e dos atores sociais ${ }^{2}$.

Nessa perspectiva, a elaboração das políticas ambientais locais pode ser apreendida como resultante de processos sociais complexos, nos quais participam grupos com interesses divergentes. Nesse sentido, o conselho pode ser visto como campo composto por atores, com habilidades sociais, que disputam visões do que é relevante enquanto problema ambiental a ser tratado pela agenda ${ }^{3}$ governamental. Diante do exposto, o presente artigo tem como objetivos mapear e discutir os interesses dos grupos em disputa contínua no Conselho de Defesa de Meio Ambiente de Maringá-COMDEMA e seus desdobramentos sobre a agenda de discussão e ação.

Para o desenvolvimento do estudo, foram realizados: revisão bibliográfica sobre o tema, levantamento de todas as atas do COMDEMA (período 1993-2006), bem como as atas do Conselho de Desenvolvimento Econômico de Maringá-CODEM, composto por atores sociais que influenciaram de forma decisiva a atuação do Conselho de Meio Ambiente (período 1993-2005). Também foram realizadas entrevistas com atores sociais chaves dos dois conselhos mencionados.

Além dessa introdução, no item 2 trata-se do conceito de campos e sua adequação para o estudo do Conselho de Meio Ambiente. O item 3 trata do surgimento e do declínio do primeiro Conselho Municipal de Meio Ambiente de Maringá atuante (1970-1995). O item 4 trata do conselho em fase recente (2001-2006) e apresenta os grandes conflitos que resultam em sua neutralização como organismo participante do planejamento ambiental. Por último, algumas conclusões.

\section{O campo das políticas ambientais como referencial teórico}

As visões de Pierre Bourdieu (1930-2002) e Neil Fligstein (1939-) partem da crítica severa à visão racionalista neoclássica, assim como do entendimento que os indivíduos agem, sempre, como maximizadores (de lucro, satisfação, bem-estar, entre outros). Eles defendem que os atores sociais estão imersos em campos organizacionais, que congregam relações entre atores/grupos sociais com poderes desiguais (político, econômico, social, entre outros) e têm como objetivo produzir regras de convivência cotidiana que preservem os privilégios do grupo dominante.

Bourdieu é conhecido por seus estudos sobre habitus, tipos de capital e, particularmente como foco do artigo, pela teoria dos campos ${ }^{4}$.

A questão que orienta sua abordagem é que o mercado é uma construção social, na qual vários grupos com diferentes poderes participam de sua estruturação. O mundo se organiza em campos interconectados, mas que se estruturam com interesses e regras próprias (campo social, campo

\footnotetext{
${ }^{1}$ O Artigo 29, itens XII e XIII, da Constituição Brasileira de 1988 (BRASIL, 1988), preconiza a cooperação das associações representativas no planejamento municipal e de projetos de lei de interesse da população local. Em vários outros capítulos da mesma, a participação popular é definida, tais como: arts. 1, 5, 194, 198 e 204, para citar alguns.

${ }^{2}$ Para uma revisão das posições, consulte Godoy (2005 e 2006).

${ }^{3} \mathrm{~A}$ formação da agenda ocorre quando uma situação qualquer é reconhecida como um problema político e a sua discussão passa a integrar as atividades de um grupo de autoridades dentro e fora do governo (RUA, 2009).

${ }^{4}$ Os conceitos de campos e habitus são relacionados, em Bourdieu. Enquadrando-se como estruturalista construcionista, ele afirma que: "Por construcionismo, quero dizer que há, de um lado, uma gênese social dos esquemas de percepção, pensamento e ação que são constitutivos do que chamo de habitus e, de outro, das estruturas sociais, em particular do que chamo de campos e grupo, e particularmente do que se costuma chamar de classes sociais" (BOURDIEU, 1990, p. 149).
} 
político, campo religioso, familiar, entre outros). Os seus posicionamentos sociais não são estáticos e sim dinâmicos, pois os agentes sociais no campo interagem e disputam constantemente uma melhor posição (BOURDIEU, 2005).

Campos referem-se às situações da vida social em que grupos organizados de atores delimitam suas ações, uns em relação aos outros, de maneira a construir uma ordem social local (BOURDIEU, 1990). É um espaço social ${ }^{5}$ no qual as organizações se espelham umas nas outras, trocam informações e tecnologias. Enfim, elas interagem, continuamente, de maneira a traçar ações, em um ambiente em que há interesses diversos e concorrência pela liderança, a qual, por sua vez, depende do capital simbólico adquirido ao longo de suas vidas.

Referindo-se ao campo econômico, Bourdieu (2005, p. 23) comenta que "os agentes criam o espaço, isto é, o campo econômico, que só existe pelos agentes que se encontram nele [...] são os agentes, isto é, as empresas, definidas pelo volume e a estrutura do capital ${ }^{6}$ específico que possuem, que determinam a estrutura do campo".

Um campo é um ambiente reconhecido pelos que dele participam em que se estabelecem relações de força destinadas a conservar ou a transformar uma situação. $O$ campo existe no momento em que é institucionalmente definido. Ele é importante para os participantes e inclui organizações que limitam, regulam, organizam e representam interesses de grupos. Os participantes interagem e constroem estruturas de dominação e padrões de coalização claramente definidos (DIMAGGIO; POWELL, 1983).

Divergindo da teoria econômica tradicional, Bourdieu (2005, p. 33) define o campo (econômico) como um campo de lutas, isto é, um campo de ação socialmente construído, dotado de agentes sociais com recursos diferentes, que disputam espaços para a apropriação do capital específico ao campo e/ou a redefinição desse capital.

Bourdieu (1990, p. 172) afirma: "O campo é simultaneamente um campo de forças e um campo de lutas que visa transformar ou conservar a relação de forças estabelecida: cada um dos agentes investe a força (o capital) que adquiriu pelas lutas anteriores em estratégias que dependem, quanto à orientação, da posição desse agente nas relações de força, isto é, de seu capital especifico".

Para que um campo exista é necessário um espaço de disputas, com agentes com posições ou capital definido ${ }^{7}$, dispostos a disputar um jogo. Portanto, todos os agentes participantes de um campo (social, político, econômico, ambiental, etc.) possuem, de um lado, interesses comuns que os unem em uma determinada estrutura social e, por outro lado, estão imersos em relações sociais que se caracterizam por interesses diversos.

Como o capital está distribuído de maneira desigual, no campo existem os dominantes (first movers ou market leaders) e os dominados (BOURDIEU, 1990). Os dominantes são aqueles que detêm o poder e privilégios conferidos pela posse do capital suficiente para exercer poder sobre os dominados. O dominante possui vantagens decisivas (constituídas pelo seu capital econômico, financeiro, entre outras) e cria estratégias para redobrar sua dominação, enquanto o ator/organização que possui pouco capital tem dificuldades em mudar a sua posição no campo e tende a ficar na posição dominada.

O campo é o espaço de relações de força entre os diferentes tipos de capital que disputam o domínio do campo e as regras que dele derivarão (BOURDIEU, 1990). Referindo-se ao campo econômico, Bourdieu (2005, p. 26) afirma: "É por meio do peso que detêm nesta estrutura [...] que as firmas dominantes exercem sua pressão sobre as firmas dominadas e sobre suas estratégias. É sua posição na estrutura [...] que faz com que elas definam as regularidades e, às vezes, a regra do jogo e os próprios limites do jogo".

O poder de ditar as regras muda no campo, considerado um espaço de conflito e competição, quando se altera a distribuição e peso relativo dos tipos de capital, quer dizer, das formas de poder. "Em cada momento, o que define a estrutura do campo é o estado das relações de força entre os jogadores", segundo Bourdieu e Wacquant (1992, p. 99).

Com base nos estudos de campos de Bourdieu, Neil Fligstein (2007) também analisa as relações de poder entre grupos com diferentes capitais. Posicionados de forma desigual no campo, os grupos se confrontam para a criação

\footnotetext{
${ }^{5} \mathrm{O}$ espaço social tende a funcionar como um espaço simbólico, um espaço de estilos de vida e de grupos de estatuto, caracterizados por diferentes estilos de vida (BOURDIEU, 1990, p. 160). Consequentemente, os atores sociais são condicionados pela interação e estrutura social, ou seja, não são analisados como agentes atomizados que agem exclusivamente em função do interesse próprio.

${ }^{6}$ A estrutura de capital, no campo econômico, discutida por Bourdieu (2005, p. 25), possui diferentes formas de capital: financeiro, cultural, tecnológico, jurídico, organizacional, comercial e simbólico.

${ }^{7} \mathrm{O}$ que determina diferentes posições no campo e, portanto, o poder de um ator frente ao outro, é a distribuição desigual das diferentes formas de capital. Em função desses recursos, os agentes elaboram estratégias de ação, no âmbito dos limites impostos pela estrutura do campo, em particular pelo seu grau de concentração (BOURDIEU, 2005, p. 25).
} 
de instituições, entendidas como regras. "Campos se referem a situações nas quais grupos organizados de atores se reúnem e desenvolvem suas ações recíprocas face a face" (FLIGSTEIN, 2007, p. 63-64).

Diferentemente de Bourdieu, que concebe que os indivíduos no campo agem contra outros indivíduos e as mudanças de atores nos grupos são bem difíceis e condicionadas ao seu capital, Fligstein considera que os atores sociais também podem agir na busca de cooperação e, portanto, eles podem apresentar diferentes formas de interação e estas produzirão as instituições ${ }^{8}$.

Fligstein (2007, p. 64) afirma: "O campo $[\ldots]$ se refere a situações nas quais os grupos organizados de atores se reúnem e desenvolvem suas ações recíprocas face a face. Compreende a capacidade de atores sociais (grupos) definirem regras e estabilizarem um conjunto de relações que os favorecem ${ }^{10}$. Nesse sentido, Machado da Silva, Guarido Filho e Rossoni (2006, p. 4) esclarecem que o campo para Fligstein é uma esfera institucional de interesses em disputa, quer dizer, são construções produzidas por organizações detentoras de poder, que influenciam as regras de interação e de dependência do campo em função de seus interesses que, por sua vez, são reflexos de sua posição na estrutura social.

Os atores, ainda segundo Fligstein (2001, p. 29), criam status hierárquicos, que definem as posições de dominante (incumbents) e desafiante (challengers). O campo atua para ajudar a reproduzir o poder e o privilégio do grupo dominante e a definir a posição do desafiante.

A ideia central de Fligstein é que, em cada campo, o objetivo central da ação está na tentativa de alcançar cooperação com outros atores. O líder (social skill) do grupo dominante precisa estabilizar suas relações com os membros de seu grupo para conseguir que estes ajam coletivamente (e, com isso, se manter como líder) e precisa estruturar seus movimentos estratégicos em direção a outras organizações em seus campos de maneira a manter o grupo como dominante.

Existe uma relação instável entre os grupos do campo, quer dizer, o grupo dominante luta para estabelecer e manter-se no poder, tanto dentro do campo quanto em outros campos (ou seja, nas relações que mantém com outras organizações, com subordinados e com o Estado, entre outros), de maneira a reproduzir suas vantagens ou a sua posição, num determinado período, através do estabelecimento de direitos de propriedade e contratos (FLIGSTEIN, 2001, p. 2, 5 e 6).

Nessa dinâmica, à medida que o grupo dominante passa a não responder em situações de instabilidade (quer dizer, não criar regras aceitas ou confiáveis para a superação da mesma por outros grupos), pode ser a oportunidade que o grupo desafiante encontra para forçar mudanças na ordem existente. Os desafiantes são bem-sucedidos quando eles são capazes de mobilizar recursos e produzir uma identidade política para conduzir o seu grupo e outros grupos numa nova situação.

Assim como em Bourdieu, Fligstein considera que o mercado consiste num jogo temporariamente estabilizado, cujas regras são provisoriamente respeitadas ${ }^{11}$. "[...] the process of institution building takes place in the context of powerful actors attempting to produce rules of interaction to stabilize their situation vis a vis other powerful and less powerful actors. Fields operate to help reproduce the power and privilege of incumbent groups and define the positions of challengers" (FLIGSTEIN, 1997, p. 8).

Com isso, as posições dos grupos no campo podem ser alteradas, a qualquer momento, pois, os atores com habilidades sociais disputam a sua direção o tempo todo.

A diversidade de visões, verificável em qualquer espaço social, conforme Gerhardt e Almeida (2005, p. 27), aponta para o fato de que as interações sociais levam a concepções específicas de meio ambiente: "Toda sociedade, toda cultura [...] irá inventar as suas concepções particulares do que representaria a ideia de meio ambiente e, consequentemente, de natureza. Logo, estas [...] noções são [...] criadas e instituídas de significados através de processos historicamente engendrados".

As políticas ambientais locais serão produto de forças que estão em contínuo confronto, ou seja, um constante

\footnotetext{
8 "Fields are viewed as socially constructed and once in place, organized around local rules of action and conceptions of membership" (FLIGSTEIN; McADAM, 1995, p. 2).

${ }^{9}$ Segundo Fligstein (2007, p. 64), “existem várias denominações para campos, entendidas como ordens sociais locais: campos (BOURDIEU, 1977; BOURDIEU; WACQUANT, 1992); campos organizacionais (DIMAGGIO; POWELL, 1983); setores (MEYER; SCOTT, 1983) ou jogos (AXELROD, 1984)”.

${ }^{10}$ Ele comenta também que a teoria dos campos assume que os atores tentam produzir estabilidade local, na qual os atores do grupo dominante produzem significados que levam a reproduzir suas vantagens. Citando Bourdieu (1977), Fligstein (2001, p. 29) assume que "the social organization of fields broadly refers to three features: the set of principles that organize thought and are used by actors to make sense of their situations (what might be called cognitive frames or worldviews), the routines or practices that actors perform in their day-to-day social relations, and the social relations that constitute fields that may or not be consciously understood by actors".

${ }^{11}$ Segundo Fligstein (2001), a estabilidade se baseia nas instituições que compreendem os direitos de propriedade, as estruturas de governança ou as normas formais e informais que interferem nas relações das empresas; as concepções de controle e das normas de transação.
} 
processo de definição e redefinição. Consequentemente, nessa concepção teórica, a problemática ambiental é continuamente construída.

O Estado, tanto para Bourdieu quanto para Fligstein, é um ator fundamental do campo, pois, os demais atores sociais são incapazes de impor regras (ambientais) e monitorá-las. Portanto, ele é o agente que transforma os acordos resultantes dos confrontos, entre os grupos no campo, em regras legais ou ações que serão implantadas.

Entende-se que o Estado, pertencente ao grupo dominante, possui uma característica singular, que é o poder de implementar ou vetar as decisões, quer sob a forma de projeto de lei, formulado nas diversas instâncias de decisão, conforme a Constituição Federal, art. 66, $\S 3^{\circ}$ (BRASIL, 1988) quer no caso do Conselho de Meio ambiente de Maringá, em que esse poder é reafirmado pela lei Complementar 09/1993, art. 34, Parágrafo Único: “Da decisão do conselho cabe recurso extraordinário ao chefe do Executivo Municipal".

Consequentemente, nesse contexto, o grupo desafiante não se torna dominante, num processo formal de substituição de organizações dirigentes, ou seja, o empresariado não assume a direção do governo quando ganha um confronto, mas sim, na disputa do espaço político, ele possui o poder de direcionamento das instituições (regras) a serem implantadas.

Nessa visão, pode-se dizer que o campo ambiental pode ser interpretado como um espaço de disputa de poder pela condução das regras, no qual atores/organizações, dotados de capital desigual, disputam a definição da estrutura do campo. Nele, portanto, se encontram dominantes e desafiantes, o que reflete a relação de forças existente na sociedade, pois, o campo é composto por um conjunto de atores sociais com relações alicerçadas em diversas formas de poder (tipos de capital).

Os conselhos deixam de ser considerados como uma organização neutra e com poder distribuído, legal e igualmente, entre os participantes. O conselho passa a ser analisado como um campo ambiental, pois, é constituído por atores sociais - representantes do setor público, setor privado e organizações não governamentais - unidos em torno de interesse comum (meio ambiente), que interagem e possuem interesses diversos. Portanto, as relações são dinâmicas: os grupos disputam, continuamente, o poder de direcionar a elaboração das políticas ambientais.
Com isso, entende-se que as políticas públicas são uma construção social e as relações no campo criam instituições que são inseparáveis da dinâmica de delimitação das políticas públicas ambientais traçadas pelos grupos, com poderes e interesses desiguais. Como campo, ele possui regras próprias decorrentes de lutas que delimitam o campo de ação e as regras de decisão (de entrada, votação, hierarquia, composição, entre outros) que permitem as relações entre eles mesmos.

Pode-se apontar também que os atores/organizações pertencentes ao campo ambiental, por terem conhecimentos e poderes desiguais, possuem diferentes concepções sobre o papel que o meio ambiente possui no desenvolvimento local e lutam permanentemente pela predominância de sua visão, quer dizer, do que estará na agenda governamental como problema ambiental.

Nesse sentido, a discussão e a formulação de políticas pelo conselho de meio ambiente podem e devem ser vistas como um jogo de poderes, em que as diretrizes negociadas como prioritárias resultam de uma disputa pela concepção de meio ambiente, que está intimamente ligada a uma concepção de desenvolvimento. As regras formais e acordos resultantes criam relativa estabilidade quanto ao papel do meio ambiente para o mercado.

Para aprofundar o teórico, discute-se o Conselho Municipal de Defesa do Meio Ambiente de Maringá, Paraná, Brasil. Chama-se a atenção de que o município tem um histórico de mobilização popular. Possui 28 conselhos temáticos, dos quais catorze são obrigatórios por lei, dentre os quais, o COMDEMA - Conselho Municipal de Defesa do Meio Ambiente, criado e recriado várias vezes, desde 1978. A Prefeitura, independente do partido no poder, tem se destacado em atividades que aumentam a participação da população nas tomadas de decisão (orçamento participativo, semana do meio ambiente, Congresso da cidade e Agenda 21). Contudo, crescem as denúncias de aumento dos problemas ambientais. Nesse contexto, defende-se que, na correlação de forças existentes, os grupos, dominante e desafiante, se confrontaram para direcionar a discussão sobre o papel do conselho e do meio ambiente no desenvolvimento local.

A seguir, apresenta-se o primeiro período de atuação do conselho. 


\section{Período 1970-1995: ascensão e queda do conselho}

Até o início dos anos 1990, as políticas ambientais (as regras, regulamentos e ações) de Maringá foram de iniciativa governamental, fragmentadas, pontuais e, em sua maioria, voltadas ao setor urbano. As diretrizes governamentais eram pouco discutidas. Contudo, nesse período, começou a se impor a ideia de planejamento vinculado ao meio ambiente e a participação da sociedade civil organizada, como reflexo da Constituição de 1988 (BRASIL, 1988).

Nesse contexto, durante o período de 1970 a 1990, conforme Bourdieu (1990), a estabilidade do campo ocorreu por intermédio da imposição pelo governo (dominante) de um conjunto de regras a outros grupos (dominados) através da força dada pelo cargo governamental. Na mesma concepção, Fligstein (1997, p. 8) afirma que "action in stable fields is a game where actors are constituted with resources and the rules are set".

Em Maringá, as dez leis ambientais promulgadas no período trataram da coleta do lixo, da criação do serviço de água e esgoto, do reflorestamento de fundo de vale para atendimento da Lei Federal 6.766/1979 (BRASIL, 1979), da criação do cemitério, da arborização urbana e do código sanitário. Eram regulamentações que visavam orientar e criar infraestrutura para o atendimento da expansão urbana em curso, na época.
Esse campo foi modificado pela Lei Complementar 09/93, art. $6^{\circ}$, que criou o Conselho Municipal de Defesa do Meio Ambiente - COMDEMA ${ }^{12}$ - e instituiu o Fundo $\mathrm{Mu}$ nicipal de Meio Ambiente, no art. $8^{\circ}$ (MARINGÁ, 1993), ou seja, surgiram as condições objetivas para a formação do campo, com discussão coletiva das políticas ambientais.

O conselho, conforme o Quadro 01, de caráter consultivo e deliberativo, retratou as forças que, na época, influenciavam as políticas ambientais locais. Ele foi composto por 15 organizações pertencentes ao governo municipal e os órgãos fiscalizadores e de assistência técnica, que atendiam às diretrizes ambientais, dos governos estadual e federal. Somou-se o empresariado que, até aquele momento, implementava suas ações de desenvolvimento local com poucas preocupações ambientais. Por último, a presença da comunidade científica (UEM) e a única ONG ambiental do município (ADEAM), que agiam de forma independente, ou seja, sem dialogar uma com a outra e pressionavam o governo para que levasse em conta os desequilíbrios ambientais, decorrentes tanto do processo de expansão urbano quanto rural.

O grupo dominante era composto por uma grande maioria ligada ao setor público e aos órgãos fiscalizadores e de assistência técnica, assim como pelo setor privado. $\mathrm{O}$ grupo dominado, formado por uma minoria (ONGs e universidade), conforme as atas analisadas, se posicionou somente em assuntos técnicos, como a criação de unidades de conservação e tombamento de árvores.

\section{QUADRO 01 - ORGANIZAÇÕES QUE COMPUSERAM O COMDEMA - 1993}

GOVERNO MUNICIPAL: Secretaria do Meio Ambiente; Secretaria da Educação do Município; Secretaria da Saúde do Município; Promotoria de Defesa do Consumidor, Meio Ambiente e Garantias Constitucionais; Secretaria de Assuntos Jurídicos; Câmara Municipal.

ORGÃOS PÚBLICOS AMBIENTAIS: Instituto Ambiental do Paraná - IAP; Instituto Brasileiro do Meio Ambiente e dos Recursos Naturais Renováveis - IBAMA; Superintendência de Controle de Erosão e Saneamento Ambiental - SUCEAM; Empresa Paranaense de Assistência e Extensão Rural - EMATER; Comissão Municipal Integrada de Solos e Águas - COMISA.

COMUNIDADE CIENTIFICA E ONG: Universidade Estadual de Maringá - UEM; Associação de Defesa e Educação Ambiental de Maringá - ADEAM; Federação das Associações de Moradores de Maringá - FEABAM.

EMPRESÁRIOS: Associação Comercial e Industrial de Maringá - ACIM.

FONTE: Dados trabalhados do artigo $7^{\circ}$ da Lei Complementar 09/93 (MARINGÁ, 1993).

\footnotetext{
${ }^{12}$ Duas tentativas foram feitas de criação do Conselho. A primeira, com a Lei n. ${ }^{\circ}$ 1.213/78 (MARINGÁ, 1978), que instituiu o Conselho Municipal de Combate à Poluição e de Defesa do Meio Ambiente e não chegou a ser implementado. A segunda com a Lei n. ${ }^{\circ}$ 2.948/91 (MARINGÁ, 1991), que instituiu o Conselho Municipal de Defesa do Meio Ambiente, o qual também não foi implantado.
} 
A estrutura imposta pelo governo municipal consistia em uma presidência, vice-presidência, secretaria e tesouraria. O campo ambiental ficou sob o controle do governo municipal, na medida em que nomeou tanto o presidente quanto todos os integrantes das diversas secretarias. Os demais atores das áreas públicas eram técnicos nomeados. Além disso, conforme se constatou em todas as atas do período (atas de $\mathrm{n}^{\mathrm{o}} \mathrm{s} .1$ a 5), houve a elaboração, a apresentação e o encaminhamento dos problemas somente pela Secretaria Municipal. Quando se abria espaço para discussão, ninguém se manifestava.

Apesar do avanço institucional, os grupos se reuniram, em quase dois anos de existência (de 14/10/1993 a 23/08/1995), apenas cinco vezes. As reuniões foram convocadas e lideradas pelas iniciativas e interesses governamentais. As ações estiveram voltadas ao setor urbano e ao ICMS ecológico, tais como: planos de manejos e recuperação das voçorocas e matas ciliares dos parques para seu enquadramento em Unidades de Conservação, arborização e lixo urbanos, reciclagem, assim como várias discussões sobre o tombamento de duas árvores, Jequitibá e Araucária, no setor urbano (ATAS DO COMDEMA, 1993 a 1995).

Constatou-se também, pelas cinco atas, que as discussões estiveram centradas na obtenção de receitas do governo estadual, através do ICMS ecológico. Nesse período, são criados três parques ecológicos municipais (Guaiapó, Palmeiras e Perobas) e discutidas medidas para recuperação de outros parques para seu enquadramento.

Conforme Ata n. 3 (13/04/1994), a Secretaria Municipal de Meio Ambiente expôs as áreas que se enquadravam no ICMS ecológico (Parque do Ingá e Bosque II) e apresentou a possibilidade de enquadrar mais quatro áreas (Horto Florestal - privado, Parque Ecológico Municipal de Guaiapó, Parque Florestal Municipal das Palmeiras e Parque Florestal Municipal das Perobas) como Unidades de Conservação, mas que, para isso, precisava da aprovação do conselho. Colocada a proposta em votação, sem qualquer discussão as Unidades de Conservação foram aprovadas por unanimidade.

Conforme entrevista realizada com Pereira de Souza (2008), o Comdema surgiu com os "objetivos de criar um órgão, que se preocupasse com o meio ambiente e atendesse à legislação federal de existir um conselho, de caráter deliberativo, para poder ter acesso a recursos do Fundo Nacional de Meio Ambiente ${ }^{13}$ e, no âmbito estadual, ter acesso aos recursos do ICMS ecológico"14. Portanto, surgiu "por iniciativa do prefeito que enviou uma lei para a Câmara e nasceu".

Apesar da possibilidade de amplo espectro de ação do conselho, por ser concebido como órgão de planejamento local ambiental, ao propor a Lei Complementar 09/93 (MARINGÁ, 1993), o Executivo delimitou a agenda de discussões no sentido de direcioná-las para a criação de Unidades de Conservação e de regulamentação para aplicação de multas na área ambiental (item X, da LC 09/93). A estratégia criada pelo governo foi de deslocar a discussão para os seus interesses de aumento das receitas governamentais.

O surgimento do Conselho de Defesa do Meio Ambiente, ainda segundo o mesmo entrevistado (2008), ocorre "sob o discurso de realizar um planejamento levando em conta o meio ambiente quando, na verdade, era para ter acesso a recursos federais e estaduais".

A preocupação maior do Executivo foi de aumentar a receita e obter as transferências do governo estadual, as quais seriam utilizadas, inclusive, para criar as condições infraestruturais para o crescimento. Nesse contexto, a função principal era criar estabilidade para atrair novos investimentos sem muitas exigências ambientais. Fligstein (2007, p. 64) comenta que um governo pode exercer a ordem e privilegiar a si mesmo ou aos seus grupos mais favorecidos.

O setor privado, nesse período, pertenceu ao grupo dominante, pois, além de atender ao requisito para a implantação do conselho ambiental de ser tripartite, ocupou esse espaço de maneira a apoiar o governo. As regras, estabelecidas em um ambiente de cooperação, tiveram muito pouca repercussão sobre o setor privado e os empresários se colocaram ao lado do governo, no sentido de apoiá-lo ${ }^{15}$. Tal arranjo de interesses, no qual o governo recebe o apoio do

\footnotetext{
${ }^{13}$ A Lei 7.797, de 10 de julho de 1989 (BRASIL, 1989), do Fundo Nacional de Meio Ambiente, estabelece em seu Artigo $3^{\circ}$ que os recursos do Fundo Nacional de Meio Ambiente deverão ser aplicados através de órgãos públicos dos níveis federal, estadual e municipal ou de entidades privadas cujos objetivos estejam em consonância com os objetivos do Fundo Nacional de Meio Ambiente, desde que não possuam, as referidas entidades, fins lucrativos. No Artigo $5^{\circ}$, as unidades de conservação são uma das prioridades estabelecidas.

${ }^{14}$ O ICMS Ecológico foi criado no Paraná através da Lei Complementar nº 59/91 (PARANÁ, 1991), com o objetivo principal de criar e manter áreas protegidas municipais (Unidades de Conservação públicas ou particulares, Áreas Indígenas ou Faxinais, devidamente identificadas no Cadastro Estadual de Unidades de Conservação, como também municípios com mananciais de abastecimento de água). Estabelece que $5 \%$ dos $25 \%$ de ICMS sejam rateados entre os municípios com as Unidades de Conservação. Dentre os requisitos, existia a criação de conselhos.

${ }^{15}$ Conforme ata n. 2 (11/11/1993), discutiu-se a lei de adoção de praças pelo comércio, na qual a prefeitura recuperava a praça e, depois, o comércio a adotava, em troca de espaço para propaganda nos bancos, lixeiras e outros. Conforme a Ata n. 4 (13/04/1994), para a Campanha "Maringá sempre limpa", o presidente da Associação Comercial e Industrial de Maringá sugeriu que as empresas emprestem seus caminhões para recolher o lixo.
} 
empresariado, que, por sua vez, não tem as regras definidas atingindo-os, permite dizer que houve uma coalizão política.

Na relação grupo dominante e dominado ocorreram conflitos, ao nível de objetivos (macro), pois, a prefeitura e seus organismos estavam preocupados em direcionar as discussões (a agenda) para o aumento da receita pública e, para isso, pressionava para a criação de Unidades de Conservação, enquanto as ONGs e a Universidade objetivavam a criação de Unidades de Conservação ${ }^{16}$ como uma das estratégias de minimização dos problemas ambientais municipais. Nesse ambiente, em que os objetivos gerais são conflituosos, o conhecimento técnico do grupo dominado direcionou algumas ações (criação de UCs e tombamento de árvores). Nesse contexto, devido ao poder de direcionamento do grupo dominante, as ações executadas pelo conselho convergiram e se limitaram a aspectos técnicos e pontuais.

Todas as iniciativas do grupo dominante se pautaram nos conhecimentos e nas diretrizes técnicas, tanto do grupo dominante quanto do grupo dominado (universidade e organismos fiscalizadores). Resultado, as regulamentações centraram-se na criação de Unidades de Conservação.

As instituições criadas, as regras do jogo estabelecidas no conselho delimitaram e, ao mesmo tempo, excluíram assuntos importantes na agenda e que tocavam diretamente o empresariado, as atividades produtivas, pois:

a) no setor agrícola, Maringá era polo na exportação de soja e trigo, com grandes problemas de utilização de agrotóxicos, desmatamento, falta de mata ciliar, assoreamento dos rios, entre outros;

b) no setor industrial, existia uma série de empresas voltadas aos setores moveleiro, confecções, alimentos, curtume e açúcar e álcool, com vários impactos;

c) o setor urbano e periurbano tinha problemas de ocupação de fundos de vale, localização de equipamentos, adensamento, verticalização das construções, dentre outros.

A delimitação das políticas ambientais (voltadas ao urbano e de caráter preservacionista) pelo conselho, por outro lado, reforçou a relação entre o Estado e setor privado na medida em que estas não interferiram na condução das atividades econômicas existentes. Houve um pacto consciente de que existiam restrições ambientais suficientes e que estas eram um empecilho ao "progresso" do município. A visão do prefeito na época, segundo entrevista realizada com Maróstica (2005), era de que "o meio ambiente só atrapalhava as ações públicas e servia de obstáculo ao desenvolvimento".

Como se pode depreender, no campo ambiental, o grupo dominante (governo, técnicos governamentais e setor privado), sob a liderança governamental, objetivou o cumprimento das leis federais e a transferência de mais recursos para o município (via cumprimento das exigências legais do ICMS ecológico). O grupo desafiante (Universidade e ONG), embora capacitado tecnicamente para denunciar os problemas existentes, não possuiu espaço para colocar as suas propostas. Esse campo foi relativamente estático devido ao poder de condução estatal e à visão predominante de que há um trade off entre o desenvolvimento e a sustentabilidade ambiental.

Entre 1995 e 2001, o COMDEMA não se reuniu, pois ele era considerado um entrave ao desenvolvimento econômico local, conforme entrevistas com Pereira de Souza (2005) e Maróstica (2005). As políticas ambientais eram traçadas ou pelo Executivo ou pelo Legislativo ou por comissões nomeadas pelo Executivo. Em termos da legislação, segundo Maróstica (2003) existiram avanços importantes, mas nem sempre implantados, como é o caso do Fórum Permanente de Preservação e Recuperação do Meio Ambiente (Lei 4.486/97), que tinha como objetivos promover discussões para a elaboração de propostas de planejamento urbano e rural para o Poder Público Municipal. Embora tenha sido promulgada a Lei Complementar 193/97, que trata das Áreas de Preservação Ambiental, continuou a prática de concessão de fundos de vale (ANTONIO, 2005). Meneguetti, Rego e Beloto (2009) comentam que os fundos de vale, em determinadas épocas, foram doados para equipamentos comunitários e, em outros períodos, passaram a ser vendidos como chácaras, com restrição de uso da faixa lindeira ao rio.

$\mathrm{Na}$ prática, as políticas ambientais (legislação e ações) eram restritas e voltadas para minimizar problemas pontuais, como: expansão urbana, impermeabilização dos solos e os loteamentos irregulares em zonas ambientais protegidas. Nos parques protegidos por lei, não houve uma política voltada ao manejo e, com isso, detectaram-se voçorocas, secamento de lagos, recepção de esgoto doméstico,

\footnotetext{
${ }^{16}$ Segundo Meneguetti, Rego e Beloto (2009), os parques e reservas florestais de Maringá encontram-se em situação bastante precária, já que sofrem uma intensa pressão pela urbanização do entorno e pela falta de reconhecimento de suas funções ambientais. Tornam-se espaços negligenciados, cuja preservação demanda policiamento constante.
} 
entre outros (MARÓSTICA, 2003; DUBIELA, 2003) e, conforme informações verbais do Secretário da SEMA ${ }^{17}$ (2010): "O município vive da fama de sua beleza e de ser uma cidade-verde". Propagandas contínuas foram encabeçadas tanto pela Prefeitura Municipal de Maringá quanto pelas organizações empresariais, as quais desejavam atrair mais capital. As denúncias tiveram pouco espaço na mídia ${ }^{18}$.

\section{4. $O$ ressurgimento do conselho: período 2001 a 2006}

A alteração da situação estável, em que o poder público era o único agente que conduzia e ditava as regras voltadas ao meio ambiente, ocorreu com a publicação do Artigo 20 da Resolução CONAMA $237 / 97$ (BRASIL, 1997), que determinou que, somente, poderão emitir licenças ambientais aqueles municípios que tiverem Conselho de Meio Ambiente, multissetorial, devidamente constituído pelo governo ${ }^{19}$.

O campo ambiental surgiu devido ao fato de que as regras vigentes não serviam mais aos propósitos governamentais. Com isso, existiu um espaço para a entrada de novos atores/organizações, que passaram a influenciar na condução das políticas públicas ambientais locais, desestabilizando o campo existente e permitindo a construção de novas instituições ${ }^{20}$.

No ano 2000, o COMDEMA foi criado (mais uma vez), sem nenhuma discussão, pela Lei complementar 352/00 (MARINGÁ, 2000), na qual se previa a participação de 18 organizações. Assim como em outras ocasiões, ele não foi implantado. Contudo, no ano seguinte, em junho de 2001, surgiu a proposta da Secretaria Municipal de Meio Ambiente de realizar o I Fórum Ambiental de Maringá, na Semana do Meio Ambiente.
O principal objetivo do Fórum foi mobilizar a cidade no sentido de "criar" o Conselho Municipal do Meio Ambiente (embora criado, legalmente, em 1978, 1991, 1993 e 2000), identificar e avaliar os principais problemas ambientais do município e estabelecer parcerias para a busca de soluções. Só que, diferentemente do que ocorreu em 1993, no campo que se formou existiam novas forças sociais para disputar o espaço de condução:

a) pela primeira vez, a gestão governamental era do Partido dos Trabalhadores;

b) além dos órgãos ambientais públicos e da UEM, participantes do conselho anterior, havia maior número de ONGs ambientais no município, com diversos interesses, enquanto que, em 1993, era somente uma;

c) existia grande mobilização empresarial, sob a égide do Conselho de Desenvolvimento Econômico de Maringá - CODEM ${ }^{21}$.

O campo começou a ser delimitado quando o governo municipal divulgou, dentro do $\mathrm{CODEM}^{22}$ e antes do Fórum Ambiental, a sua proposta de formar um conselho ambiental composto somente por ONGs e o setor público municipal. Consequentemente, essa comunicação excluía a presença dos empresários.

A exclusão do empresariado gerou, imediatamente, conflitos, pois estes tinham certeza de que seriam afetados pelo governo (várias atas do CODEM). Segundo entrevista com Araujo (2005), pertencente ao CODEM, "a proposta do governo do PT era de ser um conselho constituído por ONGs ambientalistas e setor público [...] Houve grandes discussões e grandes conflitos, na sua criação".

Nesse ambiente conturbado e de incerteza, a visão empresarial era de que sua capacidade de controle da situação estava intimamente relacionada à garantia de espaço para a criação de regras, inclusive aquelas que seriam

\footnotetext{
${ }^{17}$ Situação apresentada no evento de Extensão intitulado Contas Públicas realizado, no dia 17 de junho de 2010 , o qual contou com presença do Diretor do Meio Ambiente de Maringá, que apresentou a SEMA- Secretaria Municipal de Meio Ambiente de Maringá.

${ }^{18}$ Os donos dos jornais locais, pertencentes às organizações locais, estavam em campanha de atração de investimentos, via veiculação da propaganda "Maringá qualidade de Vida" (GODOY, 2005).

${ }^{19}$ Art. 20. Os entes federados, para exercerem suas competências licenciatórias, deverão ter implementados os Conselhos de Meio Ambiente, com caráter deliberativo e participação social e, ainda, possuir em seus quadros ou à sua disposição profissionais legalmente habilitados.

${ }^{20}$ As instituições são as regras e significados compartilhados que definem as relações sociais, ajudam a definir quem ou quais grupos ocupam qual posição nessas relações e guiam as interações, dando aos atores um conjunto de conhecimentos cognitivos para interpretar o comportamento dos outros. Elas são os procedimentos (formais e informais) que permitem guiar a aprendizagem, assegurar a dinâmica coletiva da organização (FLIGSTEIN, 1997, 2005). Sua principal função é reduzir incertezas e fornecer uma estrutura estável para o cotidiano.

${ }^{21}$ Até hoje, é o único conselho que estabelece diálogo com o governo municipal sobre a direção do desenvolvimento local, com reuniões semanais e orçamento previsto em lei. Contudo, naquela época, não tinha espaço formal para discutir as políticas ambientais (ATAS DO CODEM e ENTREVISTAS, 2005).

${ }^{22}$ Existia relativo diálogo entre a prefeitura e o CODEM, inclusive porque este apoiou na renegociação da dívida da prefeitura, quando o prefeito do PT assumiu o cargo (ATAS DO CODEM).
} 
estabelecidas pela organização que estava sendo proposta, as quais poderiam alterar os privilégios adquiridos ao longo do tempo.

Diante da resistência do governo à presença do setor empresarial no conselho e para garantir a sua presença, o CODEM, deliberadamente, mobilizou e convocou todas as lideranças para intervir no Fórum e garantir a sua presença no conselho de meio ambiente. Conforme ata 49 do CODEM (15/05/2001), os empresários criaram estratégias ${ }^{23}$ para ocupar todos os espaços de discussão existentes no Fórum. Conforme entrevista com Araujo (2005), na época, "foi necessário convocar todos os integrantes para participarem de todas as palestras e reuniões do Fórum para que o CODEM fosse indicado para cargos dentro do Conselho de Meio ambiente".

A habilidade dos atores para criar estratégias e induzir cooperação é designada como habilidade social ${ }^{24}$ (social skill). Fligstein (2007, p. 63) afirma que "todos os seres humanos têm alguma habilidade social em função de sua atuação em grupos. Contudo, alguns atores são socialmente mais hábeis em obter a cooperação dos outros, atuando como atores poderosos e sabendo em geral como construir coalizões políticas na vida". A habilidade social ${ }^{25}$ das lideranças empresariais, que participaram ativamente de todas as sessões e grupos do Fórum, foi decisiva para atingir os objetivos que almejavam e, consequentemente, poderem atuar em mais uma instância de decisão que tem desdobramentos significativos sobre o mercado privado.

Os atores com habilidades sociais pertencentes ao CODEM tiveram o poder de convencer sobre a necessidade de uma estrutura semelhante à que possuíam, para discutir as políticas ambientais. Segundo Souza (2005), ex-presidente do COMDEMA: "A proposta de estrutura foi levada ao COMDEMA, pelo [representante do] CODEM e que, na eleição da diretoria, tornou-se o vice-presidente do COMDEMA".

O resultado foi também a sua participação, inclusive, com o cargo de vice-presidente. Souza (2005) comenta: “A implantação direta da estrutura tem seus pontos positivos, pois ela é menos verticalizada, foi negociada entre o setor público e o CODEM e, portanto, tinha grande probabilidade de dar certo".

Naquele momento, a presença do empresariado era vista como avanço e como fator que garantia a sua implantação no município. Percebe-se também que a visão da ex-presidente foi de que existia uma relação positiva entre os setores público e privado, o que indica que os conflitos existentes entre o Executivo e o CODEM não chegaram a ser conhecidos no Fórum. Pode-se dizer que tanto o governo quanto o CODEM, com interesses opostos, lutaram pela liderança de suas propostas diretamente no Fórum, que votaria a questão.

O Decreto 143/02 se refere ao Decreto 09/93 (ignorou a Lei Complementar 352/00) e nomeou todas as organizações presentes na assembleia do Fórum Ambiental, 37 ao todo. A estratégia executada pelos empresários resultou em um grande acordo, que anulou tanto as ações do governo quanto garantiu a presença de todas as organizações no conselho, inclusive a do CODEM.

\subsection{As estratégias para limitar as ações do conselho e das politicas ambientais}

A estrutura proposta contemplava presidência, vice-presidência e secretário, os quais eram eleitos dentre os membros efetivos. Ainda previa 9 (nove) câmaras técnicas (CTs): Vegetação, Recursos Hídricos, Resíduos Sólidos, Política Ambiental, Fauna, Educação Ambiental, Questões Sociais, Legislação e Poluição. As CTs tinham a função de discutir relatórios, emitir pareceres e propostas, que eram apresentados em plenário e votados (ATA COMDEMA, $14 / 05 / 2002$ ).

A estrutura do conselho, comparada à anterior, representou um grande avanço no processo democrático de decisão. No campo ambiental criado pelo conselho e

\footnotetext{
${ }^{23}$ Strategic action is the attempt by social actors to create and maintain stable social worlds. This involves the creation of rules to which disparate groups can adhere. In settled times, it involves the reproduction of a given order. In this process, groups' interests and identities are created. To find these rules, actors must have a larger conception of the world (SWIDLER, 1986). These conceptions are world views that are cultural frames or templates that define what actions are legitimate and which outcomes are most desired (FLIGSTEIN, 1997, p. 4).

${ }^{24}$ Dentre as habilidades, existem as de comunicação (fazer e responder perguntas, dar e pedirfeedbaks, elogiar, iniciar, manter e encerrar conversações); as habilidades assertivas de enfrentamento ou defesa de direitos e de cidadania (expressar opinião, discordar, fazer e recusar pedidos, interagir com autoridade, lidar com críticas, expressar desagrado, lidar com a raiva do outro, pedir mudança de comportamento, etc); as habilidades sociais profissionais ou de trabalho (coordenação de grupo, falar em público); as habilidades sociais educativas de pais professores e outros agentes envolvidos na educação ou treinamento (DEL PRETTE; DEL PRETTE, 2001).

${ }^{25}$ Fligstein (2007, p. 76) chama a atenção de que a teoria da habilidade social se assemelha à ideia de reprodução hábil da vida social de Antony Giddens (1984) e da criatividade da ação social de Hans Joas (1996).
} 
exposto no Quadro 02, o grupo dominante foi formado pelo governo, com suas diversas secretarias, assim como pela Câmara de Vereadores, ONGs e a UEM e seus grupos de pesquisa, quer dizer, por aqueles que defendiam a visão de que o setor privado não deveria participar das negociações de regras ambientais. No mesmo grupo dominante, existia um relativo consenso que uma das tarefas/ações do conselho era permitir que os recursos financeiros, originados pelas multas, taxas ambientais e repasses do ICMS ecológico, fossem transferidos para a prefeitura, que tinha o poder legítimo de implementar as políticas decididas pelo conselho. No grupo desafiante, composto por atores/organizações que participavam do CODEM, existia a certeza de que os interesses privados empresariais deveriam ser preservados, portanto, seus lideres deveriam ter poder de convencimento nas discussões e encaminhamentos para preservar seus privilégios adquiridos em períodos anteriores.

Esses dois grupos possuem características muito diferentes.

A priori, o grupo dominante, além de ter o Estado, com o poder de legislar e implementar efetivamente as ações decididas pelo conselho, tem a maioria dos membros, o que poderia definir a direção das ações negociadas. Bourdieu (1990, p. 163), nesse aspecto, comenta que "as relações objetivas de poder tendem a se reproduzir nas relações de poder simbólico". Contudo, o grupo dominante é heterogê- neo, o que influiu na própria formação e no desenvolvimento do campo, como segue:

\section{1) Sua origem}

O COMDEMA foi fruto de iniciativa governamental que convocou as organizações para participar do I Fórum Ambiental e aprovar a sua "criação", de maneira a atender a um requisito legal. Como se pode deduzir, não houve discussão anterior com as organizações para eleger os "representantes". Segundo Pereira de Souza (2005), representante do CODEM no COMDEMA, "a criação do COMDEMA não foi fruto de maturação de um movimento social e sim a necessidade de cumprimento da Resolução Conama, embora, por outro lado, foi um momento democrático importante".

Nesse sentido, existiram dois problemas para o direcionamento do grupo dominante pelo governo local: o primeiro é que o campo formado compreende organizações com interesses muito diversos e que não discutiram com suas comunidades a importância do conselho e seu direcionamento político. Portanto, o grupo dominante não tinha uma base real de apoio, uma proposta comum a ser defendida. Isso caracteriza uma fragilidade no poder do grupo dominante.

Esse ambiente se diferenciou do existente no grupo desafiante, liderado pelos empresários, que foi formado por

QUADRO 02 - COMPOSIÇÃO DOS GRUPOS DOMINANTE E DESAFIANTE

\begin{tabular}{|c|c|}
\hline GRUPO DOMINANTE: & GRUPO DESAFIANTE \\
\hline $\begin{array}{l}\text { Estado: Sec. Munic. de Serviços Urbanos e Meio Ambiente, } \\
\text { Sec. Munic. de Agricultura e Abastecimento, Sec. Munici- } \\
\text { pal de Saúde, Sec. Munic. da Educação, Sec. Mun. de De- } \\
\text { senvolvimento Urbano, Planejamento e Habitação, Câmara } \\
\text { Municipal de Vereadores ( } 2 \text { repres.), Promotoria Especial de } \\
\text { Defesa do Meio Ambiente, Núcleo Regional de Educação. } \\
\text { Organizações públicas: Sanepar, Suderhsa, IAP, Emater, } \\
\text { UEM, Nupélia/UEM, Gemma/UEM e ITCA/UEM. } \\
\text { Organizações de classe: OAB, Fed. das Assoc. de Bairros- } \\
\text {-FEABAM, Cons. do Orçamento Participativo, CRBiologia, } \\
\text { Movimento Nacional de Direitos Humanos, CREA, Sindi- } \\
\text { cato dos Empregados. } \\
\text { ONGs ambientalistas: BFFS, Funverde, SPAM, Mokiti } \\
\text { Okada, Assoc.Brasil. de Defesa Ambiental }\end{array}$ & $\begin{array}{l}\text { Setor privado e associações: Sindicatos patronais e } \\
\text { cooperativas. } \\
\text { Organizações empresariais: CODEM, Assoc. Com. e } \\
\text { Ind. de Maringá, Faculdades Maringá; Cesumar. } \\
\text { Organizações religiosas: Mitra Diocesana; Ordem dos } \\
\text { Pastores Evangélicos de Maringá. }\end{array}$ \\
\hline
\end{tabular}

FONTE: Lei Complementar 393/2001 (MARINGÁ, 2001), Atas do COMDEMA e entrevistas (2005 e 2008). 
atores que querem estar na disputa pelo direcionamento das regras. Seus lideres tinham como elemento central a cooperação, a coesão em torno da proposta de ocupar o espaço de ditar as regras ambientais e reproduzir seus privilégios.

\section{2) Seu poder}

O grupo dominante internamente se constitui com poderes muito diferenciados.

O Estado, com a maioria de representantes, defendeu uma posição coesa, contudo imposta aos seus representantes, que tinham pouca autonomia. Metade dos representantes era indicada pelo Executivo, Legislativo e governo estadual. Por decorrência, nas secretarias municipais, quando não defendiam a orientação governamental, geralmente sofriam coações internas ou podiam perder privilégios e cargos. Maróstica (2005), Diretora de Meio Ambiente e, ao mesmo tempo, representante da CRBio no COMDEMA, em entrevista comentou: "Eu não sofri até agora, nada, pois minhas decisões estão pautadas em estudos técnicos, mas outros [funcionários e representantes das secretarias] sim [...] inclusive, da minha própria secretaria".

Consequentemente, atores privilegiados (governo) usaram as instituições para reproduzir a sua posição (FLIGSTEIN, 2007, p. 63), pois a estabilidade perseguida pelo Estado era importante para manter a estabilidade na condução de suas ações ambientais.

As organizações não governamentais, também pertencentes ao grupo dominante, pouco se posicionavam por dois motivos: a) pouco poder de argumentação (baixo social skill relativamente aos membros do grupo desafiante), e b) baixos conhecimentos (em comparação com os cientistas e técnicos do grupo dominante). "Não estava claro para os conselheiros nem o que era meio ambiente", comenta a ex-presidente do COMDEMA Souza (2005), o que resultava em mais um ponto de fragilidade do grupo dominante.

A UEM e seus grupos de pesquisa, também do grupo dominante, são relativamente independentes e, diante dos diversos interesses conflituosos existentes, assumiram a posição preservacionista e técnica.

Esse contexto permite apontar que o que unia o grupo dominante era a possibilidade de ter um espaço de discussão e realizações de parcerias na minimização dos impactos ambientais. Contudo, o governo, apesar de ter o controle e a direção, não conseguiu estabilizar suas relações com os membros do seu grupo para que agissem de forma coletiva e de maneira a manter a coesão e o poder de decisão do grupo.

\section{3) Seus interesses}

A proposta do governo para o COMDEMA teve como motor a possibilidade de poder legislar, captar recursos, parcerias com as ONGs e a universidade para minimizar os impactos ambientais.

Contudo, as ONGs não se posicionam nem contra os empresários (pois algumas tinham ou poderiam vir a ter relações comerciais e receber doações e/ou serviços dos mesmos), nem contra o governo (a grande maioria delas dependia dos repasses governamentais). As ONGs, que se autoindicaram no dia do Fórum, "a maioria não vai contra as iniciativas do governo e dos empresários [...] elas têm muito a perder", comenta em entrevista Pereira de Souza (2005). Nesse contexto, os atores sem recursos (de poder, financeiro e de convencimento) foram coagidos por instituições mais poderosas.

A Universidade e seu quadro de pesquisadores se posicionavam tecnicamente, independente de quem fazia as proposições.

Como resultado, pode-se afirmar que o grupo dominante era maioria, tinha poder formal de legislar, mas suas preocupações e a falta de um projeto comum comprometeram as ações de dominação e direcionamento do campo ambiental formado pelo conselho. Nesse sentido, Everett (2002) comenta que, quando se pensa em campo, deve-se analisar o poder, a dominação e as classes.

Por outro lado, o grupo desafiante, formado por organizações empresariais fortes localmente, possuía direcionamentos organizados, discutidos pelas suas bases e o objetivo claro de participar de todos os níveis de decisão do COMDEMA, principalmente os que os tocavam diretamente. Bourdieu (2005, p. 39-40) comenta que a competição entre as empresas (no caso em discussão, competição pela representação do grupo de empresários) assume frequentemente "a forma de uma competição para o poder sobre o poder do Estado, notadamente, o poder de regulamentação e sobre os direitos de propriedade [... ] usando poderes detidos pelo Estado, que são capazes de controlar".

Consequentemente, o grupo desafiante tinha como objetivos limitar as ações e regras formais que impedissem a manutenção de seus interesses e privilégios econômicos. Pode-se apontar que o campo foi estruturado e entendido, por aqueles que dele fazem parte, como relações entre posições objetivamente definidas e decorrentes dos tipos de poder (ou capital), cuja posse comanda o acesso aos lucros específicos (no caso, privilégios), que estão em jogo no campo. 


\subsection{As lutas no campo ambiental}

Cada líder de grupo participante do conselho criou estratégias e agiu como social skill baseado em sua concepção de problemas ambientais, de maneira a influenciar e criar instituições sobre o papel do meio ambiente no desenvolvimento econômico. É a condição que Fligstein (1997) coloca como sucesso na concepção de controle, a qual depende de dois elementos: a habilidade social e a capacidade de criar soluções para os problemas existentes.

Em cada grupo, dominante e desafiante, o objetivo central da ação era alcançar cooperação para obter a maioria em uma votação. Para isso, as pessoas com maior social skill agiam como líderes e criavam estratégias para conseguir adeptos que defendessem a sua posição. Fligstein (2007) comenta que as organizações tentam controlar outros atores, no sentido de conseguir estabilidade nas relações e acesso aos recursos. Como as instituições são construções sociais, a direção das políticas ambientais foi disputada entre os grupos desafiante e dominante e, de maneira singular, dentro do próprio grupo dominante.

O Estado, para impedir o direcionamento do grupo desafiante (empresários, predominantemente), criou obstáculos para o desenvolvimento do poder dentro do seu próprio grupo, de maneira a poder continuar exercendo o direcionamento das políticas sozinho, isto é, estrategicamente ele deixou de induzir cooperação com seus aliados. Com a pressão e a percepção dos interesses dos grandes grupos econômicos, pertencentes ao grupo desafiante, as habilidades sociais dos representantes do governo se deram no sentido de limitar e mesmo impedir a evolução do próprio grupo dominante. Para começar, entre o término do I Fórum e a posse dos membros do conselho, dia 18 de março de 2002, decorreram mais de nove meses. O objetivo foi esvaziar de significado o conselho, de maneira que ele, somente, continuasse a atender os requisitos impostos pela normatização.

As disputas pelo papel que o conselho e o meio ambiente teriam no desenvolvimento local são apresentadas a seguir.

\subsubsection{As lutas entre o grupo dominante e o grupo desafiante}

O primeiro confronto entre os grupos ocorreu na reunião de instalação da direção do conselho. A eleição da diretoria explicitou os interesses antagônicos e a disputa pela direção das políticas ambientais locais. De um lado, no grupo desafiante, os empresários objetivavam a direção formal, uma cadeira na diretoria do conselho, para ter o controle sobre o que ocorria. De outro lado, no grupo dominante, os cientistas da UEM defendiam que o setor produtivo não deveria ter representantes, pois poderia haver uma distorção nos objetivos e comprometimento do conselho e, mesmo, desvirtuamento das propostas: "Como se garante que se vai multar a empresa que faz parte do conselho?", comentou Souza (2005), ex-presidente do conselho e cientista.

Nesta luta, ocorreu a primeira vitória do grupo desafiante ao ocupar posto-chave no conselho. Conforme Ata (01/04/2002), a eleição da diretoria ocorreu por autoindicação. Nesse contexto, tem-se o grupo organizado do desafiante e o que tem dificuldade de se organizar, o dominante. No caso da presidência, houve a inscrição da UEM, representante legislativo e de uma ONG. Para a vice-presidência, houve a inscrição de duas organizações que fazem parte do CODEM e a mesma ONG.

No caso da presidência, os argumentos utilizados foram do direcionamento "apolítico" e sem "atender aos interesses dos empresários", complementados pela visão técnica e de proteção integral dos recursos naturais. Com isso, o Nupélia/UEM fica com a presidência, pois "o princípio acordado entre os diferentes atores ali presentes era que deveria prevalecer a técnica, em vez do político e do setor privado" (SOUZA, 2005).

Ao se estabelecer esse direcionamento, assumiu-se que seriam cumpridas as leis existentes e, na falta das mesmas, as decisões seriam norteadas pelo parecer técnico. Consequentemente, na disputa, o grupo desafiante obteve vantagens, pois a decisão se pautava pelo rigor da lei, que os empresários já conheciam e, em diversos níveis, vinham cumprindo, o que mantinha relativa estabilidade nas atividades econômicas existentes. Quanto ao não previsto por lei, as possíveis normas, pautadas pelo técnico e pelo conhecimento acumulado, particularmente presente no grupo dominante, necessariamente, passariam pelo plenário do conselho, espaço que o grupo desafiante ocupava e sobre o qual tinha influência. Os atores sociais hábeis fizeram o necessário para alcançar os fins coletivos do grupo desafiante. Seu nível de organização e seu poder econômico foram barreiras efetivas para as tentativas dos técnicos e cientistas de ampliar o escopo de ação do conselho. Como resultado, institucionalmente, o conselho decidiu por se pautar pela preservação dos recursos naturais, 
cumprir as normas ambientais existentes e tomar decisões baseadas em pareceres técnicos. "O conselho é de defesa do meio ambiente, então ele deve preservar o meio ambiente, toda a ação está na preservação", comenta a ex-presidente Souza (2005).

Com isso, as propostas de políticas ambientais de manejo e conservação não possuíram espaço no COMDEMA. Eliminou-se essa discussão, que permitiria avanços em direção ao desenvolvimento com sustentabilidade ambiental. Estavam delimitadas as "novas" institucionalidades que norteariam as políticas públicas ambientais.

No entanto, isso não foi suficiente para o grupo desafiante e ocorreram conflitos constantes com o grupo dominante, em particular com os técnicos e cientistas. "Enquanto no CODEM todos os membros estão voltados para a economia, no COMDEMA uns poucos estão preocupados com o meio ambiente e outros estão lá para atrapalhar as ações do conselho. Existem organizações no conselho que entram para trabalhar contra o conselho [ela se refere aos empresários]", comenta Souza (2005).

Outra vitória do grupo desafiante foi o cargo de vice-presidente, que foi ocupado por um representante do CODEM, um empresário. Em meados de 2004, quando ocorreu nova eleição, o representante do CODEM foi eleito presidente. A partir de então, o COMDEMA, sob essa direção, ficou quase dois anos sem se reunir e só no final do ano de 2005 passou a se reorganizar. Houve total esvaziamento da organização, pois, a presidência tinha poder de agenda, não convocou as reuniões e neutralizou as ações do conselho.

Além disso, as ações estavam centradas no setor urbano: qualidade da água consumida, ligações clandestinas em galerias pluviais, arborização urbana, Agenda 21, logomarca, loteamentos em área de preservação no Parque Tarumã ${ }^{26}$, escola de jardinagem e lixo urbano. As estratégias traçadas tornaram consensual que estes eram os problemas ambientais de Maringá. Como se pode constatar, eles estavam ligados à administração e gestão públicas e não às atividades econômicas existentes.

Em nenhum momento, conforme as atas do período e entrevistas realizadas, o conselho avançou nas políticas agrícolas, industriais e urbanas. "Não se discutiu: política industrial, uso de recursos naturais, crescimento da cidade, planejamento e expansão urbana, política agrícola, cemitério, nascentes de água e fundos de vale", comentam Souza (2005), Pereira de Souza (2005) e Maróstica (2005).

Devido aos conflitos, o COMDEMA não teve espaço de discussão de ações e políticas de curto, médio e longo prazos. A estabilidade alcançada significou a reprodução da ordem existente.

\subsubsection{As lutas no grupo dominante}

Na época da instalação do COMDEMA, como já foi discutido, os objetivos do governo municipal eram de ter uma visão dos problemas ambientais, implantar algumas iniciativas e cumprir a Resolução CONAMA para arrecadar tributos.

Em entrevista, Maróstica (2008) enfatiza o caráter facilitador da existência de conselhos e afirma que: “Após ano 2000, devido aos recursos em nível federal estarem vinculados à existência de conselho atuante [...] facilitou a sua formação, tudo que você vai fazer em termos de solicitação de recursos, em nível federal, você tem que provar que o teu município possui um conselho atuante".

Para isso, a composição proposta por ele, de ONGs ambientalistas, universidade e setor público, era coerente. Contudo, a mudança no quadro institucional - ou seja, as pressões e a entrada dos empresários na formulação das regras do jogo - resultou em conflitos e reformulação do campo. O governo municipal passou a criar estratégias que tanto atendiam as suas demandas quanto minimizavam ou anulavam a força do empresariado.

A posição do governo em relação ao grupo desafiante se refletiu na condução política e burocrática do grupo dominante. No lugar de fortalecer sua base de apoio, as relações dentro do grupo dominante se tornaram mais complexas, pois o governo passou a criar barreiras para o próprio funcionamento do conselho. Com o poder conferido pelo cargo, ocorre o que Fligstein (2007, p. 71) alerta, que é o fato de que os atores estratégicos em grupos dominantes começarão a agir, em uma situação de crise, tentando defender o status quo e, ao reforçar a sua posição, continuarão a utilizar a estrutura em seu favor.

A primeira estratégia foi não repassar os recursos financeiros para o conselho. Apesar de aprovado o Fundo

\footnotetext{
${ }^{26}$ O Conjunto Tarumã, loteamento da década de 1990, estava em cima de lençóis d'água rasos. Alguns anos mais tarde, esses lençóis ocasionaram uma intensa infiltração sob as construções. Em 2004, mais de 40 casas foram desapropriadas e os moradores foram indenizados. Nenhum laudo geoambiental foi realizado. A empresa privada que vendeu os lotes, na prática, transferiu a responsabilidade da desativação da área ao Poder Público.
} 
Municipal de Meio Ambiente, pelo Decreto 09/93 (MARINGÁ, 1993), nunca foram repassados recursos para o mesmo. "Não tem dinheiro nem para selo", comenta Souza (2005).

O Conselho também não tinha local - "As reuniões ocorrem cada dia em um lugar. Depende-se do que é viável, na época" (SOUZA, 2005) - e nem infraestrutura para se reunir, diferentemente do tratamento dado ao CODEM (que mantinha boas relações com a Secretaria de Desenvolvimento e tinha acesso a recursos - Fundo Municipal de Desenvolvimento - que lhe permitiam ter infraestrutura adequada).

$\mathrm{Na}$ estrutura aprovada, não existia uma secretaria executiva e, esta, segundo todos os entrevistados, era vital para o funcionamento do COMDEMA. A falta da mesma, além de sobrecarregar a presidente e a secretária do conselho, em termos de tempo de tramitação burocrática, gerou desperdício de massa crítica que poderia ser aproveitada para alavancar a discussão sobre a política ambiental do município. Fligstein (2007, p. 64) chamou a atenção para o caso em que o governo, no grupo dominante, utiliza o poder que a legislação lhe dá para reproduzir as suas vantagens e a sua posição.

Para forçar a mudança, o governo se alia a outros grupos (externos ao campo ambiental) para implantar estratégias de cerceamento das ações do conselho. Na Ata de 24/04/2003, por exemplo, o Secretário de Urbanismo comunica ao COMDEMA que o projeto do Novo Centro estava aprovado e que o Conselho não poderia paralisar as obras, pois já tinha sido aprovado pelo CODEM (o grupo dos empresários).

Tal decisão fez com que o grupo dominante se fragilizasse e iniciasse um confronto político. Os técnicos e cientistas do grupo dominante entraram em conflito direto com o governo local (Câmara de Vereadores, Secretaria Municipal de Meio Ambiente e a Comissão de Assessoramento para Recuperação de Fundo de Vale) por perderem espaços importantes de decisão. Como resultado, na Ata de 16/07/2002, o Secretário de Meio Ambiente comunicou que o COMDEMA não era a instância para discutir Fundo de Vale, venda de pneus usados e distribuição de gás no setor urbano ${ }^{27}$. "A prefeitura decide que as questões de meio ambiente passem antes pela Câmara dos Vereadores e não pelo Conselho" (SOUZA, 2005).
O governo local teve como estratégia fragilizar o grupo dominante e, por consequência, impedir a ação de social skill do grupo desafiante através da retirada de espaços de decisão. Para isso, além de reforçar outros campos externos, passou a repassar responsabilidades do conselho para outras organizações governamentais ou criou novas instâncias, nas quais o seu controle foi assegurado. Conforme comentários verbais da Secretaria de Agricultura e Meio Ambiente, órgão ao qual o conselho está atrelado: “A atuação do COMDEMA está restrita ao cumprimento do artigo [...], nada mais [...] mandamos a demanda prevista em lei, que eles devem responder e só".

A criação ou utilização de instâncias decisórias paralelas ao conselho acabou limitando o acesso às informações e impôs ao conselho um papel secundário no direcionamento das políticas, o que reforçou (se é que deixou de existir) a visão de que a prioridade era o desenvolvimento/ crescimento econômico, encabeçada por campos externos ao estudado. O papel do COMDEMA tornou-se cada vez mais limitado. As políticas ambientais passaram a ser, em sua maioria, centralizadas nas mãos do governo, correspondendo a um retrocesso no campo ambiental.

\subsection{O esvaziamento (deliberado?) do Conselho}

Um elemento que permitiu o relativo fortalecimento do grupo desafiante e da direção empresarial foi o fato de que o Conselho de Meio Ambiente passou a ser palco de atendimento de demandas pontuais das ONGs participantes. Estas e outras organizações que participaram do conselho (diversas associações de bairros, catadores de lixo, PC do $\mathrm{B}$, entre outros) entenderam o conselho como um local para dirigir suas demandas e exigir respostas.

Se, por um lado, isso foi positivo e mostrou o potencial de mobilização do Conselho, por outro lado, as organizações reforçaram uma visão míope e corporativista do Conselho, na medida em que o conselho passou a ser entendido como espaço de demandas pontuais de organizações isoladas.

Os atores do grupo desafiante foram hábeis socialmente no sentido de reforçar esse conteúdo e, com isso, o

\footnotetext{
${ }^{27}$ Vários conflitos ocorreram com o Legislativo, conforme Ata de 18 fev. 2003. Com isso, o Conselho recebeu o Oficio 404/03 - Câmara Municipal que afirmava: "O Poder Legislativo não pode se submeter à relação de dependência e subordinação pretendida pelo COMDEMA" (Ata de 15 abr. 03). Houve rompimento entre o legislativo e o conselho, o Conselho perdeu seu papel de influenciar as leis ambientais, que estavam sendo discutidas pelo Legislativo. Isso, por sua vez, fortaleceu o Executivo e o próprio empresariado, que possui um espaço de discussão, formal e semanal, com a Secretaria de Indústria, Comércio e Turismo.
} 
grupo dominante, progressivamente, deixou de lado o seu papel mais importante, que era o de discussão das políticas ambientais locais. Fligstein (2007) comenta que os atores sociais hábeis, muitas vezes, acabam convencendo os outros de que o que conseguem é o que eles querem.

Várias outras características dos participantes reforçaram o esvaziamento do conselho.

A primeira foi o fato de que os confrontos entre os grupos dominante e desafiante envolveram pessoas com poderes de argumentação e convencimento muito desiguais, ou seja, "doutores e pessoas semianalfabetas", como comentou Souza (2005), o que provocou o desinteresse nos debates por parte dos participantes. As questões tratadas, além de exigirem a experiência, requerem algum grau de conhecimento técnico, o que pede uma maior escolaridade dos conselheiros.

Diversas atas apontaram ausências e trocas constantes de conselheiros e isso impediu a formação de um corpo de conselheiros que trabalhasse, rotineiramente, com objetivos comuns, determinados e sintonizados. Verificou-se a falta de envolvimento dos conselheiros em levar adiante as poucas propostas formuladas. Ocorreram desligamentos de instituições que poderiam contribuir para o direcionamento das políticas ambientais (Secretaria da Educação, Instituto Ambiental do Paraná, Faculdades Maringá, Associações de Bairros, Associação dos Coletores de Lixo, entre outros).

Os conselheiros ligados às ONGs não iam contra as propostas formuladas tanto pela prefeitura quanto pelos empresários. "Além de baixíssima representatividade [...] Existem muitos interesses em jogo", salienta Souza (2005). Consequentemente, na hora das decisões, grande parte do grupo dominante não se posicionava, o que reforçou tanto os interesses do governo (que não queria que o empresariado ampliasse seu poder) quanto reforçava o grupo desafiante (que tinha interesse na fragilidade, na inatividade e na baixa representatividade do conselho).

Como resultado, os problemas ambientais tratados pelo conselho foram socialmente construídos de maneira a limitar a sua ação político-social. Nesse contexto, o pressuposto de que o campo ambiental é um espaço social privilegiado das discussões deve ser visto com reservas, pois o campo formado em Maringá, com atores sociais que se organizaram e criaram estratégias visando atender aos seus interesses específicos, resultou no cerceamento de suas atribuições.

\section{Algumas conclusões}

É importante reconhecer que o desenvolvimento local sustentável é uma construção social. Essa construção, por sua vez, não permite simplificar o argumento de que na sociedade existem, de um lado, os interesses empresariais e, de outro, os do Estado e organizações sociais ou que dependam do partido no poder.

A teoria dos campos permitiu verificar que as estratégias traçadas pelos grupos, dominante e desafiante, permitiram que os mesmos atores sociais/organizações, em alguns momentos, se associassem e, em outros, se confrontassem, dependendo do momento histórico e dos poderes em jogo.

Nesse contexto, aponta-se que existem complexas relações entre os grupos que constroem coletivamente o campo ambiental. Se, por um lado, o conselho, predominantemente, foi utilizado como instrumento para referendar as decisões adotadas pelo poder público local, por outro lado, foi possível perceber que este é um importante espaço coletivo de discussão.

Infelizmente, no caso estudado, as relações conflituosas, estabelecidas tanto entre o grupo dominante e o grupo desafiante quanto dentro do grupo dominante, resultaram na restrição ao máximo da atuação, assim como no cumprimento das leis existentes. "No final, o COMDEMA cumpre as exigências legais", afirma a Secretária do Conselho, Maróstica (2005).

No caso de Maringá, os interesses conflitantes dos empresários e do governo, os diferentes modos de pensar o papel do conselho e do meio ambiente e as estratégias políticas definidas acabaram por diminuir o espaço de ação e deliberação do conselho, que se restringiu ao aspecto técnico, entendido como "neutro", e pouco avançou com as discussões das políticas ambientais de médio e longo prazos. Somou-se a isso a forte dependência (financeira e política) entre o gestor municipal e as diversas organizações participantes.

Esse contexto permite afirmar que as relações construídas socialmente se afastam da aplicação, pura e simples, dos receituários de condicionantes de um bom conselho. Destacam-se os interesses individuais e organizacionais em jogo, o poder do conhecimento e discernimento das temáticas ambientais e sua influência no desenvolvimento local, o poder de convencimento de atores hábeis, a assimetria informacional tanto intergrupos quanto intragrupo, entre outros. 
O confronto pela direção das políticas ambientais locais também é contínuo e ocorre entre grupos que consideram o meio ambiente, mas que dão valores/pesos diferentes a ele. Os grupos que irão influenciar as políticas ambientais locais disputam a direção desses valores/pesos no conselho, o tempo todo.

\section{Referências}

ANTONIO, Daliana C. L. Maringá: a ordem desejada. Urutagua, n. 7, dezembro, 2005.

ATAS DO CODEM - período 1996 a 2005.

ATAS DO COMDEMA - 1993 a 2005.

BOURDIEU, Pierre. Coisas ditas. São Paulo: Brasiliense, 1990. 15-58, 2005.

O campo econômico. Política \& Sociedade, v. 6, p.

; WACQUANT, Loïc J. D. (Eds.). The purpose of reflexive sociology (The Chicago Workshop). In: BOURDIEU, Pierre; WACQUANT, Loïc J. D (Eds.). An invitation to reflexive sociology. Chicago: Chicago University Press, p. 1-59, 1992.

BRASIL. Lei n. 6766, de 19 de dezembro de 1979. Dispõe sobre o parcelamento do solo urbano e dá outras providências. Disponível em: <http://www.planalto.gov.br/ccivil_03/Leis/ L6766.htm>. Acesso em: 05/06/2005.

Constituição da República Federativa do Brasil, de 05 de outubro de 1988. Disponível em: <http://www.senado. gov.br/legislacao/const/con1988/CON1988_05.10.1988/ CON1988.shtm>. Acesso em: 05/06/2005.

. Lei 7.797, de 10 de julho de 1989. Cria o Fundo Nacional de Meio Ambiente e dá outras providências.

CONAMA - Conselho Nacional do Meio Ambiente. Resolução n. 237, de 19 de dezembro de 1997. Disponível em: <http:// www.mma.gov.br/port/conama/res/res97/res23797.html>. Acesso em: 10/06/2005.

DEL PRETTE, A.; DEL PRETTE, Z. A. P. Habilidades sociais: conceitos e campo teórico-prático, 2001. Disponível em: $<$ http://www.ribs.ufscar.br>. Acesso em: 10/04/2011.

DIMAGGIO, P.; POWELL, W. The iron case revisited. American Sociological Review, v. 47, p. 147-160, 1983.

DUBIELA, V. T. Qual o nosso "destino" tropical? Políticas públicas para os fundos de vale de Maringá-Paraná. Dissertação (Mestrado em Geografia) - Universidade Estadual de Maringá. Maringá, 2003.
Com base na experiência apresentada, pode-se apontar que a construção e o funcionamento dos conselhos estão permeados pelas heranças institucionais, quer dizer, pela ordem existente que recebe a influência do passado e influenciará a construção do futuro.

EVERETT, J. Organizational research and the praxiology of Pierre Bourdieu. Organizational Research Methods, v. 5, n. 1, p. 56-80, 2002.

FLIGSTEIN, Neil. Fields, Power, and Social Skill: A Critical Analysis of The New Institutionalisms. Berkeley: University of California Press, 1997. Disponível em: <http://www.irle.berkeley.edu/culture/papers/Fligstein3.pdf $>$. Acesso em: 05/2006.

. The architecture of markets: an economic sociology of twenty-first-century capitalist societies. New Jersey: Princeton University Press, 2001.

. The Political and Economic Sociology of International Economic Arrangements. In: SMELSER, Neil; SWEDBERG, Richard. The Handbook of Economic Sociology. New Jersey: Princeton University Press, 2005.

. Habilidade social e teoria dos campos. RAE - Revista de Administração de Empresas, v. 47, n. 2, p. 61-80, abril/ junho de 2007.

; McADAM, Doug. A political-cultural approach to the problem of strategic action. Berkeley: University of California Press, January 1995. Paper disponível em: <http://sociology. berkeley.edu/profiles/fligstein/pdf/DOGPAP.03.pdf $>$. Acesso em 10 de outubro de 2005.

GERHARDT, Cleyton H.; ALMEIDA, Jalcione. A dialética dos campos sociais na interpretação da problemática ambiental: uma análise crítica a partir de diferentes leituras sobre os problemas ambientais. Ambiente e Sociedade, v. VIII, n. 2, p. 1-33, jul./dez. 2005.

GODOY, A. M. G. Uma proposta de análise dos conselhos de desenvolvimento. In: ENCONTRO DE ECONOMIA PARANAENSE, 4., 10 nov. 2005, Toledo. Anais... Toledo, 2005.

. Movimentos sociais de base empresarial: contradição nos termos ou sinal dos tempos? Relatório (Pós-Doutorado em Ciência Ambiental) - PROCAM/USP. São Paulo, 2006.

MACHADO DA SILVA, Clovis L.; GUARIDO FILHO, Edson R.; ROSSONI, Luciano. Campos organizacionais: seis diferentes leituras e a perspectiva de estruturação. RAC-Revista 
de Administração Contemporânea, Edição Especial, v. 10, p. 156-196, 2006.

MARINGÁ. Lei 1.213, de 21 de junho de 1978. Institui, no município de Maringá, o Conselho Municipal de Combate à Poluição e de Defesa do Meio Ambiente e dá outras providências. Disponível em: <http://sapl.cmm.pr.gov.br:8080/ sapl_documentos/norma_juridica/2994_texto_integra $>$. Acesso em: 05/06/2005.

. Lei 2.948, de 07 de outubro de 1991. Institui o Conselho Municipal de Defesa do Meio Ambiente. Disponível em: $<$ http://sapl.cmm.pr.gov.br:8080/sapl_documentos/norma_juridica/4729_texto_integral $>$. Acesso em: 05/06/2005.

Lei complementar 09, de 03 de junho de 1993. Dispõe sobre a política de proteção, controle, conservação e recuperação do meio ambiente no município de Maringá. Disponível em: $<$ http://www.jusbrasil.com.br/legislacao/662394/ lei-complementar-9-93-maringa-pr>. Acesso em: 05/06/2005.

. Lei 4.486, de 03 de outubro de 1997. Institui o Fórum Permanente para a preservação e recuperação do meio ambiente no município de Maringá. Disponível em: <http://sapl.cmm. pr.gov.br:8080/sapl_documentos/norma_juridica/6267_texto_integral $>$. Acesso em: 05/06/2005.

. Lei Complementar 352, de 22 de setembro de 2000. Altera a redação da Lei Complementar n. 09/1993 (dispõe sobre a política de proteção, controle, conservação e recuperação do meio ambiente no município de Maringá). Disponível em: $<$ http://sapl.cmm.pr.gov.br:8080/sapl_documentos/norma_juridica/609_texto_integral $>$. Acesso em: 05/06/2005.

. Lei Complementar 393, de 01 de novembro de 2001. Altera dispositivos da lei complementar n. 09/1993, que dispõe sobre a política de proteção, controle, conservação e recuperação do meio ambiente no município de Maringá. Disponível em: <http://sapl.cmm.pr.gov.br:8080/sapl_documentos/ norma_juridica/650_texto_integral $>$. Acesso em: 05/06/2005.

MARÓSTICA, Lídia M. da F. Gestão Ambiental Municipal: o licenciamento como ferramenta de controle para o município de Maringá-PR. Dissertação (Mestrado em Geografia) - Universidade Estadual de Maringá. Maringá, 2003.

MENEGUETTI, Karen S.; REGO, Renato L.; BELOTO, Gislaine E. Maringá: a paisagem urbana e o sistema de espaços livres. Paisagem e Ambiente, São Paulo, n. 26, p. 29-50, 2009.

MMA/BID - Ministério do Meio Ambiente/Banco Interamericano de Desenvolvimento. Diálogos de política social e ambiental: aprendendo com os Conselhos Ambientais Brasileiros. Primeira Parte. Brasília, 2002.
OSTROM, Elinor. The drama of commons. Disponível em: $<$ http://books.nap.edu/catalog/10287.html $>$. Acesso em: 15/05/2004.

PARANÁ. Lei Complementar n. 59, de 01 de outubro de 1991. Dispõe sobre a repartição de $5 \%$ do ICMS, a que alude o art. $2^{\circ}$ da Lei 9.491/90, aos municípios com mananciais de abastecimento e unidades de conservação ambiental, assim como adota outras providências. Disponível em: $<$ http://www.aguasparana. pr.gov.br/arquivos/File/lei5991.pdf $>$. Acesso em: 10/04/2011.

RIBOT, J. C. Decentralized natural resource management: Nature and democratic decentralization in sub-Saharan Africa: A summary report prepared for Symposium on Decentralization Local Governance, 2004. Disponível em: <http://www. uncdf.org/english/local governance/thematic papers $>$. Acesso em: 06/2005.

RUA, Maria das G. Politicas públicas. Florianópolis: UFSC/ CAPES, 2009.

TONI, Fabiano. La gestión florestal en los municipios de la Amazonia Brasileña. In: FERROUKHI, L. (Ed.). La gestión forestal municipal en América Latina, 2003. Disponível em: $<$ http://www.cifor.org/doc.rec.htm>. Acesso em: 05/07/2004.

; KAIMOWITZ, David. Municípios e gestão florestal na Amazônia: introdução e marco teórico. In:

Municípios e gestão florestal na Amazônia. Natal: AS Editores, 2003. p. 32-33.

\section{Entrevistas realizadas}

ARAUjO, Álvaro G. E de. Técnico do CODEM, entrevista concedida a Amalia M. G. Godoy, 23 de maio de 2005.

MARÓSTICA, Lidia. Diretora de Meio Ambiente da Prefeitura Municipal de Maringá e representante do Conselho Regional de Biologia - CRBIO - no COMDEMA. Entrevistas concedidas a Amalia M. G. Godoy, em abril de 2005 e abril de 2008.

PEREIRA DE SOUZA, Paulo Roberto. Representante do CODEM no COMDEMA. Entrevista concedida a Amalia M. G. Godoy, em abril de 2005 e abril de 2008.

SOUZA, Maria Conceição de. Representante da UEM e ex-presidente do COMDEMA. Entrevista concedida a Amalia M. G. Godoy, em maio de 2005.

Recebido em junho de 2011. Aceito em julho de 2011. Publicado em dezembro de 2011. 